\title{
An Evaluation of Green School Program at SMA Negeri 1 Selong as a Preparation Towards a Swaliba School
}

\author{
* Anggun Dwi Utami \\ Student Geography of Science, Padang State University, INDONESIA \\ Email: anggunutami517@gmail.com
}

*Corresponding Author, Received: January 15, 2018, Revised: March 02. 2018, Accepted: May 20, 2018

This is an open acces article distributed under the Creative Commons 4.0 Attribution License, wich permits unregtricted use, Distribution, and reproduction in any medium provided the original work is properly cited @2017 by author and Universitas Negeri Padang

\begin{abstract}
This research was aimed to: 1) know the policies applied by the leaders of SMA Negeri 1 Selong (state senior high school 1 Selong) to components of education with respect to the implementation of Green School Program, 2) study students' and teachers' activeness and participation in the implementation of Green School Program, 3) study the inhibiting factors of Green School Program implementation, 4) evaluate physical condition of the school according to SWALIBA concept. This qualitative research was set at SMA Negeri 1 Selong in East Lombok Regency. Research population were all residents of SMA Negeri 1 Selong. Before collecting the data, a stratified proportional random sampling was conducted in order to select sample from population. Then, data was obtained through observation, questionnaire, interview and documentation. The result of this research showed that (1) Green School Program had been well implemented according to Adiwiyata guidelines. SWALIBA concept had been practiced and this was evident from curriculum changes that supported management of the environment, integration of environmental materials in school subjects, various environmental action, and the management of eco-friendly facilities by using Green House and Compost House. (2) The school had held some activities that involved students in Adiwiyata Program. School residents also supported Green School Program and it was represented by the level of their participation both in the terms of energy, idea, skill, money and goods. (3) There were no meaningful inhibiting factors because the school could solve them. As a preparation in improving Green School Program to SWALIBA, an evaluation of school physical condition which is in accordance to the concept of SWALIBA was done on environmental indicators. The suitability of environmental indicator variables highly supported the development of SWALIBA concept in SMA Negeri 1 Selong.
\end{abstract}

Keywords: Land Green School, Swaliba (Environmentally Friendly and Disaster Mitigation Based School), Evaluation

\section{Introduction}

In this 21 st century, the most talked environmental issue is climate change due to an increase of Carbon concentration in the air which is often called a global warming. Global warming is caused by, one of them, deforestation that can reduce the ability of carbon uptake in the air. Since World War II, the number of motor vehicle in the world has been increasing from 40 million units to 680 million units. It is a human product that can cause carbon emissions in atmosphere, so in this case humans are the main actors that determine 
whether or not an environment is damaged (Worosuprojo, 2008). Experts from various fields have been holding conferences discussing about the way to solve that problem. One of them is Scientific Conference of Indonesia Geographer Association which was held on 22nd-23rd of November 2008 in Universitas Negeri Padang (UNP) and discussing about educational or un educational efforts that could be done to reduce the effect of global warming on geography worlds. One of the most basic preventive measures is through changing one's behavior in order to do action and have attitude that can reduce the impact of global warming. This can be done through instilling loving-the-environment attitude to students as early as possible by educational institution in school environment (Syafri, 2008).

One of educational programs in Indonesia whose purpose is to promote awareness to act wisely in environment is Adiwiyata Program. Adiwiyata program is included in Environmental Education Policy which has been agreed on 19th of February in 2004 by four ministries of Indonesia consisting Ministry of Environment (KNLH), Ministry of Education, Ministry of Religion, and Ministry of Internal Affairs. This policy serves as basic guidelines for stakeholders in implementing and developing PLH (environmental conservation) in Indonesia and as one of solutions in the effort to improve society's knowledge and understanding towards the preservation of environmental functions (the handbook of Adiwiyata, 2011).

Adiwiyata program offers various concepts such as Green School, Healthy School, Eco School, and others. Green School is a government program which is hoped to be able to give understanding and awareness and integrate environmental values to all school residents in order to create eco-friendly behavior and management pattern of the school in preserving environment. Green School Program has became an important icon in the efforts to anticipate global warning because by developing students' sense of responsibility, care, and confidence in Elementary School and Junior and Senior High School, all school residents are participating to minimize the global warming. US Green Building Council (USGBC) defined "green school as school buildings or facilities that create healthy and conducive environment for learning and save energy, resources, and money" (Ramli et al., 2012). Furthermore, green school is the result of consensus planning process of environment and building design and construction which takes into account its performance over 50-60 years (Gordon, 2010; Ramli et al., 2012). Moreover, sustainable school or green school can create a good learning environment (Olson and Kellum, 2003; Ramli et al., 2012). A sustainable school does not only include the concept of sustainability but also learning instruments that support the concept (Ramli et al., 2012). The definition of green school in Indonesia refers to the Regulation of the Ministry of Environment number 05 Year 2013 in respect of Adiwiyata Program Guidelines. It stated that Adiwiyata school is an ideal and good school that serves as a place to gain knowledge, norms, and ethics which are used as a foundation to create human welfare and sustainable development model (KLH, 2013). Evaluation system for Adiwiyata (green) schools in Indonesia requires them to satisfy four components consisting of: 1) Environmental policy, 2) the implementation of environmental curriculum, 3) participative environmental activities, and 4) eco-friendly infrastructures and eco-friendly facility management (KLH, 2011) .

In the booklet of SWALIBA, it is mentioned that in order to face massive and various hazard potentials around environment where learners live, other than developing wise behavior towards the environment, it is necessary to create an individual who can adapt to the condition of his/her environment or create an individual who are resilient to disasters. Based on that relation, an idea is generated saying that what Indonesia needs today is to create humans who can live in harmony with disasters. Considering several things above, a concept needs to be arranged for the sake of developing an educational institution which is able to implement them. This concept is then manifested in the development of Environmentally Friendly and Disaster Mitigation Based School (SWALIBA) throughout Indonesia.

Green School program in SMA Negeri 1 Selong of East Lombok Regency has been implemented long before Government Policy of Adiwiyata is made. The government of East Lombok Regency itself has made the area of SMA Negeri 1 Selong as a cultural heritage area because it is a Dutch heritage. Physical condition of the environment is still original and beautiful despite its location in the middle of town. The emergence of Government Regulation of Adiwiyata actually reinforces further development of Green School concept and is as well as the follow-up of workshop about School Environmental Management which is participated by teachers of SMA Negeri 1 Selong. Based on those preliminary findings, the researcher was motivated to do an evaluation on Green School program and school members' participation in the program implementation followed by providing insight to disaster and developing disaster responsive attitude for the students. The 
importance of an insight to disaster and disaster responsive attitude is because East Lombok Regency is one of disaster-prone areas with potentials of Tsunami, Earthquake, flood, and landslide. So, in the future the program of Green School in SMA Negeri 1 Selong can be improved to SWALIBA that will be assisted by IMAHAGI (geography student association of Indonesia) and inaugurated by IGI (Geographer Association of Indonesia).

\section{Method}

Type of research in this research using descriptive approach. The method is a qualitative method, where this research focuses on describing the implementation of Adiwiyata program and school efforts in increasing the participation of learners in Adiwiyata program in school. A descriptive approach is a study directed to provide systematic and accurate symptoms, facts, or events about the nature of a particular population or region (Nurul Zuriah, 2006). The research was conducted at SMA Negeri 1 Selong, East Lombok regency. The type of data in this study is the primary data. The research subjects are all components of education in SMA Negeri 1 Selong, the sampling technique using stratified proportional random sampling. The subjects of this study are (Adiwiyata School Team, Headmaster, School Vice Dean for Infrastructure, School Public Relations, Teachers, Employees and Students). Data collection techniques used are: Observation (Observation), Interview (Interview), Documentation. Data analysis using Miles and Huberman model. This research aims to 1) to know the policies applied by the leadership of SMA Negeri 1 Selong to all components of education regarding the implementation of Green School Program, 2) to assess the level of activeness and participation of teachers and students in Green School Program implementation, 3) to examine the factors which impedes the implementation of the Green School Program, 4) evaluates the physical condition of schools in accordance with the SWALIBA concept.

\section{Results and Discussion}

Green School is a school that commits and systematic develops programs to internalize environmental values in all school activities (Sugeng Paryadi, 2008). A school can be environmentally friendly when it can apply and develop the four main pillars that become indicators and criteria of the school, including 1) policy development of a care and environmentally cultured school, 2) the development of environmental curriculum, 3 ) the development of participative environmental activities, and 4) the management and/or the development of school supporting facilities. Participation is mental, emotional and physical involvement of a member in giving initiative to activities launched by an organization, in this case school, and supporting goal achievement and being responsible for her/his involvement (Suryosubroto, 2009). Participation in this research is student's and teacher's involvement in implementing the program of Green School in SMA Negeri 1 Selong in terms of energy, idea, skill, goods and money. Environmentally friendly and disaster mitigation based school or SWALIBA is a concept designed for creating an educational vessel or institution that can implement and create humans who are able to coexist with disasters (Booklet Swaliba:16). All the concept is generated into two indicators, namely Environmental indicators such as air and light, plants, waste, water, energy, health and culture and disaster indicators such as disaster-resistant building and building plan, place and evacuation route, disaster map, signs and disaster warning systems, rescue equipments, management system, and disaster mitigation training. The program of Green School and SWALIBA have something in common, that is a program based on environment. It is just that SWALIBA broadly reviews an insight into disaster. Green School program implemented in SMA Negeri 1 Selong will be improved to SWALIBA by adding disaster knowledge, developing infrastructures and school curriculum and these will be assisted by SWALIBA supporters, IMAHAGI, especially III regional IMAHAGI .

Based on observations and interviews shows that the Green School program has been implemented well in accordance with Adiwiyata guidelines. The educational component at SMA Negeri 1 Selong strongly supports the measurable Green School program of implementing environmentally sound policies in schools conducted in accordance with the adiwiyata manual. Characterized by the change of vision and mission of the school in accordance with the values and efforts of environmental protection and management, then in the 
structure of the curriculum also contains the competence of graduates who have attitudes, knowledge, and skills of self-development. School RAKS has also been allocated for $20 \%$ of the total school budget for the program in environmental protection and management efforts. Schools have also developed an environment-based curriculum in ways that are integrated with subjects. Almost all subjects in school have been integrated with environmental insight. In addition to being integrated with the subjects, environmental education in schools also raises the monolithic subjects of Cultivation and Workshop. In terms of school participation level is quite good seen from the participation component education in SMA Negeri 1 Selong in the form of energy, thoughts, skills, money and goods. Where the form of activities carried out is the joint picket, environmental action held every Friday. Then utilize the land and facilities according to environmental principles through: making ponds, Green House, garden and compost house. In addition to the creativity and innovation of school residents in efforts to protect and manage the environment through: making compost fertilizer, sanitation management, publication of artworks, publications of scientific papers. In the fourth criterion is the management of environmentally friendly means which includes procurement, utilization, and maintenance. Procurement of environmentally friendly facilities in schools is done by direct purchase and grant from several agencies that have established cooperation in Adiwiyata program. such as trash cans, garbage carts, horticultural crops, horticultural crops and banners of environmental theme day lists, Green House development, compost houses, and ponds. In the utilization of environmentally friendly facilities in schools is the use of Compost House and Green House as a means of learning of learners. The forms of learning facilities are the making of compost and plant cultivation. While in maintenance focuses on improvements such as rehab and cleaning. This is because the environmentally friendly means of hygiene and health. Eco-friendly facilities such as biopore and bathroom. The cleaning of the bathroom checked the cleanliness every once a week. But if in a few days it is dirty, it must be drained or cleaned immediately. the last criterion is the school effort in involving students. Schools have sought a variety of efforts to engage students. The effort is carried out through various environmental actions that have been held by the school, namely: Agenda clean-up together every Friday, sorting waste, Seminar or Workshop Environment, Following environmental actions conducted by outsiders and from schools, the establishment of Task Force Adiwiyata. In the implementation of green school program in SMA Negeri 1 Selong there are several obstacle factors such as in the use of environmentally friendly means that the narrowness of compost house is used as a means of learning of learners, so that it can only accommodate half the class. Furthermore, in the maintenance of the management of environmentally friendly means, where some of the environment is neglected and not maintained during rehab. In addition, lack of cooperation among teachers and lack of personnel in caring for environmentally friendly means. But some of the inhibiting factors can be overcome by schools as school preparation in developing Green School Program become SWALIBA, as school preparation in developing Green School Program become School of Environmental and Disaster Mitigation, study of evaluation of school physical condition in accordance with SWALIBA concept has been done on environmental indicators are divided into 7 variables namely air and light, plants, waste, water, energy, health and culture. The suitability of the seven variables is very supportive for the development of SWALIBA concept in SMA Negeri 1 Selong.

\section{Implementation of Adiwiyata Program in SMA Negeri 1 Selong}

\section{Environmentally Friendly School Policy}

The practice of environmentally friendly policy in the school was carried out based on the handbook of Adiwiyata. In the development document of KTSP, school had included the policies to protect and manage environment. This was signed by the changes of school mission and vision in accordance with values and efforts to protect and manage environment as explained by the team leader of Adiwiyata in SMA Negeri 1 Selong. Moreover, curriculum structure already contained competence of graduates who had attitude, knowledge, and self-development skill. School budget work plan (RAKS) of the school was allocated about $20 \%$ of total school budget for the program in efforts to protect and manage environment. The program of environmental protection and management was including: students, curriculum and learning activities, the improvement of educational capacity and teachers, and eco-friendly facilities. Environmental management in the school was supported through various environment based activities for example cleaning day on every Friday and every world environment day. 


\section{Environmental Curriculum}

Environment based curriculum or environmental curriculum which was developed by the school for the sake of protecting and managing environment was integrated in school subjects. Amos Noelaka (2008) stated that subjects that can be integrated with environmental materials are for example physics, chemistry, biology, cultural anthropology and geography. Almost all school subjects had been integrated with environmental concept. Other than that, environmental education in the school also brought up monolithic subjects of cultivations and craft.

\section{Participative Environmental Activities}

Participative environmental activities are done according to the standards of Adiwiyata school which have been assigned by Ministry of Environment and Ministry of Education. In the handbook of Adiwiyata (2012:21), the first standard of activity is maintaining and taking care of building in school environment by school residents. The activities done in SMA Negeri 1 Selong were jointly cleaning duty and environmental action on every Friday. Then, the second standard is using the land and facilities based on environmental principles, for example making of ponds, green house, garden and compost house. The third criteria is the creativity and innovation of school residents in an effort to protect and manage the environment. It was done through, for example producing compost, managing sanitation, and publishing scientific work. Environmental actions were not only held by the school itself but the school also participated in the actions organized by other instutions. As mentioned in the handbook of Adiwiyata (2012), standards of participative environmental activity is also including school's participation in the activity of environmental action organized by outsiders. In order to Improve environmental management, the school was supported by various parties such as school alumni, Regional Environmental Agency, Provincial Environmental Agency, Regional Disaster Management Agency (BPBD), Education Authorities, Public Work Service (DPU) of East Lombok Regency, and Public Health Office of Selong.

\section{Management of Eco-friendly Facilities}

The procurement of eco-friendly facilities in school was done through direct purchase and grants from institutions who had been cooperating in Adiwiyata program. The facilities were like trash bin, garbage cart, horticultural plants, environmental-day-list banner, green house building, compost house, and ponds. The source of funds of eco-friendly facilities was from special fund allocation of Adiwiyata which had been included in school budget. The utilization of eco-friendly facilities in school was the utilization of compost house and green house as student's learning facilities. By using the facilities students learned how to produce compost and cultivate crops. The utilization depends on the extent to which subjects are given by teachers. The problem was narrow compost house that can only accommodate half of students. To solve the problem the school expanded it. Eco-friendly facility maintenance is the responsibility of Associate Vice Principal (Facilities and Infrastructures). It is focus on improvement such as repairing and cleaning because the facility is concerned with hygiene and health. The facilities like biopore holes and bathrooms are not directly cleaned after use. The cleaning is usually done once in a week. However, if in a few days they are dirty they should be immediately drained or cleaned.

\section{School's Effort to Involve the Students}

School had tried to make various efforts to involve students. those efforts were done through various environmental activities organized by the school such as: Agenda of every Friday's jointly cleaning duty, waste sorting, environmental seminar or workshop, participating in environmental actions organized by the school or other institutions, and forming Adiwiyata task force. In the implementation of the adiwiyata program in SMA Negeri 1 Selong almost all of them meet the criteria of adiwiyata, it is just a little constrained in the utilization of environmentally friendly means of narrow composting house which is used as a learning tool for learners, so it can only accommodate half the class. Furthermore, in the maintenance of management of environmentally friendly means, where some of the environment is abandoned and unkempt during rehab. In addition, the lack of cooperation among teachers and the lack of personnel in taking care of environmentally 
friendly means. So in the implementation of green school programs in SMA Negeri 1 Selong that have not met the criteria that is in the utilization and maintenance management of environmentally friendly means.

\section{Conclusion}

Based on the description of the research results in SMA Negeri 1 Selong then can be drawn conclusion as follows: The implementation of Green School program in SMA Negeri 1 Selong is in accordance with Adiwiyata Guide book. It is marked by the policy of changing the mission vision that contains environmental values, the integration of environmental insight materials in subjects both in subjects and extracurricular activities, carrying out environmental action activities both organized by schools and those held by outsiders, and utilizing Green House facilities and Rumah Kompos for learning. Schools in an effort to increase the participation of learners in the green school program have implemented a variety of special activities. These activities include, among others, the formation of the Adiwiyata Task Force, following environmental action activities organized by both the school and outsiders and attending seminars or workshops. The policies and actions implemented by school leaders in the implementation and development of the Green School Program are entirely guided by indicators and criteria set by the Ministry of Environment. The overall implementation/development/management of the school environment has been well implemented and has met the criteria that have been set, the participation rate of teachers and students on the implementation of Green School Program is divided into 5 types of participation. Participation in the form of energy, thoughts, skills, goods and money. In the implementation of green school program in SMA Negeri 1 Selong there are several obstacle factors such as in the use of environmentally friendly means that the narrowness of compost house is used as a means of learning of learners, so that it can only accommodate half the class. Furthermore, in the maintenance of the management of environmentally friendly means, where some of the environment is neglected and not maintained during rehab. In addition, lack of cooperation among teachers and lack of personnel in caring for environmentally friendly means. But some of the inhibiting factors can be overcome by schools as school preparation in developing Green School Program become SWALIBA, as school preparation in developing Green School Program become School of Environmental and Disaster Mitigation, study of evaluation of school physical condition in accordance with SWALIBA concept has been done on environmental indicators are divided into 7 variables namely air and light, plants, waste, water, energy, health and culture. The suitability of the seven variables is very supportive for the development of SWALIBA concept in SMA Negeri 1 Selong.

\section{References}

Amos Noelaka. (2008). Kesadaran lingkungan. Jakarta: PT. Rineka Cipta

Anwar, Syafri. (2008). Alternatif Kebijakan Sekolah dalam Mewujudkan Program Go Green School sebagai Antisipasi Dampak Pemanasan Global. The paper was presented in National Seminar Proceeding, 10th Annual Scientific Conference of IGI in 2008 in Universitas Negeri Padang, 22nd-23rd of November. Sukabina Press.

Arikunto, Suharsimi. (2010). Prosedur Penelitian: Suatu Pendekatan Praktik. Jakarta: Rineka Cipta.

Gordon, D. E. (2010). Green Schools as High Performance Learning Facilities. Washington, D.C.: National Clearinghouse for Educational Facilities. Retrieved from http://www.ncef.org/pubs/greenschools.pdf

Hasanah, Nur. (2011). Implementasi Program Green School pada pembelajaran IPS di SMP Negeri 9 dan 15 Tegal. Undergraduate Thesis. Semarang: Geography Program in Faculty of Social Sciences. http://nedutaslingkungan.blogspot.com/p/konsep-green-school.html 
IMAHAGI. Sekolah Berwawasan Lingkungan dan Mitigasi Bencana. Sebuah Pendidikan yang mampu hidup harmoni dengan Kondisi Alam Geography Student Association of Indonesia. index.php/download_file/view/14063/3930. Ancaman Bencana di Jawa Tengah.doc.
Konsep Peningkatan Mutu Indonesia. Booklet. http://www.bappenas.go.id/

Kementerian Lingkungan Hidup dan Kementerian Pendidikan dan Kebudayaan. (2012). Panduan Adiwiyata: Sekolah Peduli dan Berbudaya Lingkungan. Jawa Tengah: Badan Lingkungan Hidup

Monalisa. (2013). Program Adiwiyata dalam Pengelolaan Lingkungan Sekolah di SMPN 24 Padang. A journal of Geograhy Education Vol 1, No 01 (2013) UNP.

Nanik Hidayati, Tukiman Taruna dan Purnaweni, Hartuti. (2013). Perilaku Warga Sekolah dalam Program Adiwiyata di SMK Negeri 2 Semarang. Jurnal Ilmiah. Semarang: UNDIP.

Nurfasani, Layla R. (2013). Hubungan Antara Persepsi tentang Lingkungan Sekolah yang Sehat terhadap Tingkat Partisipasi Siswa dalam Pembentukan Lingkungan Sekolah Sehat di SMP NEGERI 1 Mrebet. Undergraduate Thesis. Semarang: Geography Program in Faculty of Social Sciences UNNES.

Nurul Zuriah. (2006). Metodologi Penelitian Sosial dan Pendidikan: Teori - Aplikasi. Jakarta: PT Bumi Aksara.

Tim Adiwiyata Tingkat Nasional. (2011). Panduan Adiwiyata Sekolah Peduli dan Berbudaya Lingkungan. Kerjasama Kementerian Lingkungan Hidup dengan Kementerian Pendidikan dan Kebudayaan.

Olson, S. L., \& Kellum, S. (2003). The Impact of Sustainable Buildings on Educational Achievements in K12 Schools. Wisconsin: Leonardo Academy Inc. Retrieved from http://www.cleanerandgreener.org/download/sustainableschools.pdf

Paryadi, Sugeng. (2008). Konsep Pengelolaan Lingkungan Sekolah (Green School). Modul. Cianjur.

Ramli, N. H., Masri, M. H., Taib, M. Z. H. M., \& Hamid, N. A. (2012). A Comparative Study of Green School Guidelines. In Procedia - Social and Behavioral Sciences (Vol. 50, pp. 462- 471). http://doi.org/10.1016/j.sbspro.2012.08.050

Santoso, Kukuh. (2004). Pengantar Ilmu Lingkungan. Semarang: UPT UNNES Press.

Sastropoetro, Santoso. (1988). Partisipasi, Komunikas, Persuasi dan Disiplin dalam Pembangunan Nasional. Bandung: Alumni.

Sugiyono. (2008). Metode Penelitian Kuantitatif Kualitatif dan R\&D. Bandung: Alfabeta.

Suryosubroto. (2004). Proses Belajar Mengajar di Sekolah. Jakarta: Rineka Cipta.

Widiyanto, Kukuh. (2011). Partisipasi Siswa SMA Negeri 11 Semarang dalam Pelaksanaan Program Sekolah Hijau (Green School). Undergraduate Thesis. Semarang: Geography Program in Faculty of Social Sciences.

Worosuprojo, Suratman. (2009). Merespon Perubahan Iklim Global Apresiasi Konsep Mitigasi dan Adaptasi. In opening speech of the National Seminar, 10th Annual Scientific Conference of IGI in 2008 in Universitas Negeri Padang. 